\title{
Performance Appraisal as an Antecedent to Innovation: an Analysis of Its Relative Importance
}

\author{
Navin Gazanchand Matookchund (Corresponding author) \\ Graduate School of Business Leadership, University of South Africa, \\ PO Box 396, 0003 Pretoria, South Africa \\ E-mail: navin.matookchund@ sasol.com \\ Renier Steyn \\ Graduate School of Business Leadership, University of South Africa, \\ PO Box 396, 0003 Pretoria, South Africa \\ E-mail: steynr@unisa.ac.za
}

Received: Jan. 30, 2020 Accepted: Feb. 26, 2020 Published: Mar. 17, 2020

doi:10.5296/ijhrs.v10i2.16697ＵRL: https://doi.org/10.5296/ijhrs.v10i2.16697

\begin{abstract}
Literature suggests that performance appraisal (PA) contributes to innovation. However, the absolute and relative importance of PA to innovation, the different aspects of PA which drive innovation, as well as PA as a precursor among other antecedents to innovation, has not been adequately described. The aim of the study is to provide clarity on the drivers of innovation, specifically contextualising the impact of PA within the South African context. This study used a cross-sectional survey design, where only quantitative data was collected from full-time employees across private sector, parastatal, and government organisations. The respondents represented a broad cross-section of South African employees. PA and three other known antecedents to innovation, as well as innovation itself, were measured. It was found that PA (as a single variable) was responsible for $5.7 \%$ of the variance in innovation. Items in the PA scale with a clear link to innovation were identified, and thematically integrated. It was further found that, when PA was combined with other antecedents of innovation, leading to $26.6 \%$ of the variance in innovation being explained, the role of PA was significant, though mostly secondary. Proactive personality was the most dominant predictor of innovation. The importance and relative importance of PA as an antecedent to innovation in the workplace has thus been established. The outcomes of this study may assist
\end{abstract}


managers and human resource practitioners to focus on appropriate, evidence-based information when attempting to enhance innovation.

Keywords: corporate entrepreneurship, innovation, performance appraisal, proactive personality, South Africa, transformational leadership

\section{Background}

Innovation is a prerequisite for organisational survival in the global business environment (Abbaspour, 2015; Ceylan, 2013; Runfeng, 2011). In addition, Akman and Yilmaz (2008) recognise innovation as a key success factor in a progressively competitive international economy. Competitive advantage and growth can be realised and sustained only through periodic or continuous innovation (Abbaspour, 2015; Hurley, \& Hult, 1998; Muller, Valikangas, \& Merlyn, 2005). By the same token, Ryakhovskaya, Gruzina, Arsenova, Linder, and Pukhova (2015) and Wu, Sears, Coberley, and Pope (2016) argue that innovation, along with other variables such as collaboration, is viewed as a source of competitive advantage.

There are many antecedents to innovation. These include leadership (Paulsen, Callan, Ayoko, \& Saunders, 2013; Tipu, Ryan, \& Fantazy, 2012), organisational climate (Michaelis, Stegmaier, \& Sonntag, 2010; Shanker, Bhunugopan, \& Fish, 2012), organisational culture (Michaelis et al., 2010; Tipu et al., 2012), organisational design (Michaelis et al., 2010), performance appraisal (PA) (Aktharsha, \& Sengottuvel, 2016; Choi, Moon, \& Ko, 2013; Dalota, \& Perju, 2010; Runfeng, 2011), proactive personality (PP) (Seibert, Kraimer, \& Crant, 2001; Tai, \& Mai, 2016), and generic human resource practices (HRPs) (Aktharsha, \& Sengottuvel, 2016; Dalota, \& Perju, 2010; Matthew, 2014). Considering HRPs, Aktharsha and Sengottuvel's (2016) study revealed that there are three main HRPs, namely PA; recruitment and selection; and compensation and reward that are significant predictors of knowledge sharing behaviour. It has already been established that knowledge sharing behaviour plays an important role in predicting innovation capability (Aktharsha, \& Sengottuvel, 2016). Also referring to specific practices, the study by Dalota and Perju (2010) presents evidence that specific HRPs, namely PA, rewards, career opportunities, and employee participation, result in innovation. Dalota and Perju (2010) posit that the utilisation of HRPs within an organisation could encourage employees to generate innovative ideas that promote innovation. Also, with reference to innovation, Shipton, West, Dawson, Birdi, and Patterson (2006) found that PA plays an important role in predicting innovation capability. Swanepoel, Erasmus and Schenk (2008) affirm the aforementioned and state that the measurement of employee performance is vital to the organisation achieving its goals and objectives.

Evidence of empirical research on the link between PA and innovation is seemingly lacking within the South African context. It is also not surprising that much of the PA-innovation research is conducted primarily within the Western context (Dalota, \& Perju, 2010; Jimenez-Jimenez, \& Sanz-Valle, 2005). This research will attempt to fill this specific void.

Although some studies (e.g., Bal, Bozkurt, \& Ertemsir, 2014; Jimenez-Jimenez, \& Sanz-Valle, 2005; Mark, \& Akhtar, 2003; Shipton et al., 2006) have uncovered a link between 
PA and innovation, the research on the PA-innovation link has often been single-company or single-industry driven and undertaken with relatively small samples. This study will explore the relationship both organisation-wide and across sectors.

Also, as noted by DeNisi and Pritchard (2006), much of the research has been limited to examining PA as a free-standing concept rather than as an integral part of performance management and other organisational variables. Published research in which other antecedents are included in the analysis of the PA-innovation link is scarce, whereas this study will attempt to include several other antecedents in the model.

The investigation of the PA-innovation link is also a very pressing problem from a business perspective, given the importance of innovation, as highlighted in the first paragraph, and given the amount of money and time that organisations devote to the development and administration of PA systems (Grote, 1996; Khoury, \& Analoui, 2004).

\subsection{Research Problem}

Literature suggests that PA contributes to innovation. However, appropriate knowledge with regard to the relative importance of PA, the various aspects of PA which are linked to innovation, and PA as a precursor among other antecedents to innovation, is not adequately described. The absence of nuanced information pertaining to the PA-innovation relationship may result in the inappropriate allocation of resources to PA which, in turn, may impede the organisation's success. Furthermore, this link has not been well investigated in South Africa, where organisational and cultural conditions may be unique.

\subsection{Aim}

The article aims to investigate the importance of PA as an antecedent to innovation in the workplace, focusing on the aspects of PA, PA as a single concept, and the relative importance of PA as a driver of innovation compared to other antecedents of innovation.

\section{Literature Review}

DeNisi and Pritchard (2006), and Esu and Inyang (2009) argue that successful organisations exploit HRPs, such as PA, as management tools to improve performance and effectiveness. PA is one of the most vital components of human resource management practice (Boswell, \& Boudreau, 2000; Judge, \& Ferris, 1993) and contributes to continuous improvement in the present business environment (Ahmed, Mohammad, \& Islam, 2013).

PAs are regularly discussed in the literature and applied in practice. Almost all organisations globally make use of some sort of PA system (DeNisi, \& Pritchard, 2006; Nankervis, \& Compton, 2006), therefore human resource researchers and practitioners alike have devoted close to a century to PA research (DeNisi, \& Pritchard, 2006; Siaguru, 2011).

PAs are utilised for a multitude of purposes, such as decision-making with regard to compensation, promotions, retention, and developmental needs and, if conducted effectively, can significantly contribute to employee motivation and satisfaction (DeNisi, \& Pritchard, 2006; Grobler, Wärnich, Carrell, Elbert, \& Hatfield, 2011). PA systems should incorporate all 
those facets of human resource management that advance the effectiveness and efficiency of both the organisation and the employee (Khoury, \& Analoui, 2004). Khan (2013) thus states that the PA system is an important component of the performance management process which links company goals and daily performance achievements, as well as individual development and rewards. Grobler et al. (2011) likewise indicate that PAs are key to the development of an organisation's human capital.

The link between PA and innovation has been empirically established according to studies conducted by researchers Jimenez-Jimenez and Sanz-Valle (2005), and Mark and Akhtar (2003), who suggest that PA is an important HRP responsible for innovation. Bal et al. (2014), Jimenez-Jimenez and Sanz-Valle (2005) and Shipton et al. (2006) establish that there is a strong and positive link between PA and innovation. Specifically, Shipton et al. (2006) argue that PAs that are focused predominantly on employee development foster innovation. Chen and Huang (2009) indicate that organisations with highly effective PA systems achieve superior innovation results.

It is interesting to note that the effect of PA on innovation may be indirect. Ling and Nasurdin (2011), for example, suggest that workers achieve better results in innovative undertakings as effective PAs increase worker satisfaction and commitment. In the study by Ling and Nasurdin (2011), it was also demonstrated that PAs are positively correlated to knowledge management effectiveness. These researchers found that knowledge management effectiveness completely mediates the link between PA and innovation (Ling, \& Nasurdin, 2011). In the study conducted by Runfeng (2011), the author found that organisational innovative climate mediate the PA-innovative behaviours relationship. This supports the notion that PAs have indirect effects on innovation.

PA is however not the only antecedent to innovation. It is apparent from the literature that transformational leadership (TL), organisational climate and proactive personality (PP) are significant predictors of innovation. In studying the leadership literature on innovation, Sethibe and Steyn (2015) report that researchers focused almost exclusively on TL when studying the relationship between leadership and innovation. TL is positively and significantly related to innovation according to Paulsen, et al. (2013), Sethibe and Steyn (2016), and Tipu et al. (2012). Another important antecedent to innovation is organisational climate (Michaelis et al., 2010; Panuwatwanich, Stewart, \& Mohamed, 2008; Shanker et al., 2012). According to these authors Michaelis et al. (2010), Shanker et al. (2012), and Zhang and Begley (2011), there is a significant relationship between climate and innovation. Another important precursor to innovation is PP, which significantly and positively relates to innovative behaviour (Seibert et al., 2001; Tai, \& Mai, 2016). Parker, Williams and Turner (2006), Seibert et al. (2001), and Thomas, Whitman, and Viswesvaran (2010), posit that PP is the main determinant of innovative behaviours.

It becomes clear from the literature that TL, organisational climate and PP are significant predictors of innovation. It would be important to study the relative importance of PA, given these other antecedents to innovation, to specify the role it plays in promoting innovation at work. 


\section{Method}

In this section, the research approach, measuring instruments and statistical analysis are presented.

\subsection{Research Approach}

A cross-sectional survey design, which focused on quantitative data, was used for this study. Bryman (2012) and Punch (1998) note that a quantitative research design strategy is appropriate for this type of study as it readily allows the establishment of relationships between variables.

The data was collected as part of a research project led by the second author of the study. Only South African organisations formed part of the study. The sample for the organisations was not random, but rather a convenience sample. Once the organisations had been identified, respondents were selected at random from the organisation's employee records. Ultimately, data consisted of 3180 employees from 53 organisations. The data was collected in accordance with the ethics guidelines of the University of South Africa (UNISA), and permission was obtained from the UNISA Research Ethics Review Committee to use the data.

\subsection{Measuring Instruments}

The five instruments utilised for this study were the Quality of a Performance Appraisal System Questionnaire (PA; Steyn, 2010), the Innovative Work Behaviour Questionnaire (IWB; De Jong, \& Den Hartog, 2010), the Proactive Personality Scale (PP; Bateman, \& Crant, 1993), a part of the Leadership scale, specifically the Transformational Leadership scale portion (TL; Wolins, 2012), and the Brief Corporate Entrepreneurship Assessment Instrument (CE; Strydom, 2013).

- The PA questionnaire, developed by Steyn (2010), was employed to assess the perceived effectiveness of PA systems in organisations. This questionnaire is based on human resource management literature (Cascio, 2010; Grobler, Wärnich, Carrell, Elbert, \& Hatfield, 2006; Swanepoel et al., 2008) which describes the characteristics of an effective PA system. Grobler et al. (2006) provide a full list of necessities for an effective PA system, and the majority of the literature was therefore adapted from these authors. The PA questionnaire comprises 18 statements designed to elicit the respondent's views on the PA process. Respondents were invited to indicate their views for each item on a five-point scale ranging from 1 to 5 as follows: 1 (Absolutely false - this is true in $+/-10 \%$ of all cases), 2 (Somewhat false - this is true in $+/-35 \%$ of all cases), 3 (Neither true nor false), 4 (Somewhat true - this is true in $+/-75 \%$ of all cases), and 5 (Absolutely true - this is true in $+/-90 \%$ of all cases). The lowest score that could be obtained was 18 , and the highest was 90 . A high score would be indicative that a traditionally defined PA system was in place and functioning effectively, while a low score would indicate that the respondents were convinced that a traditionally defined PA system was not functioning in their organisation (Steyn, 2010). Furthermore, Steyn (2010) reports internal consistency to have a Cronbach alpha of 0.84 and significant correlations (in 
the expected direction) with results such as turnover intentions $(\mathrm{R}=0.311 ; p<0.01)$, job satisfaction $(\mathrm{R}=0.281 ; \mathrm{p}<0.01)$ and employee engagement $(\mathrm{R}=0.318 ; p<0.01)$.

- The IWB questionnaire from De Jong and Den Hartog (2010) was selected as it measures the dependent variable, innovative behaviour. The IWB questionnaire consists of 10 questions. The existing IWB questionnaire had to be modified for the purposes of this study. No measurement scale was provided in the De Jong and Den Hartog (2010) article. A scale was therefore introduced, ranging from (0) Never to (6) Always. The lowest score that could be obtained was 0 and the highest 60 . The following is a question from the original IWB questionnaire: 'How often does this employee...pay attention to issues that are not part of his daily work?' (De Jong, \& Den Hartog, 2010: 29). This format did not suit the study, which emphasises the views of individuals concerning their IWB. All ten items of the questionnaire were thus amended to begin 'As an employee how often do you...' instead of 'How often does this employee...'. De Jong and Den Hartog (2010) report that the instrument is adequately reliable (Cronbach alpha>0.7). According to De Jong and Den Hartog (2010), there is clear evidence that employees' innovation outputs $(\mathrm{R}=0.35 ; p<0.01)$, participative leadership $(\mathrm{R}=0.25 ; p<0.01)$ and external work contacts $(\mathrm{R}=0.27 ; p<0.01)$ correlate with IWB and this points to good criterion validity. The adapted version of the instrument was used for this research.

- The PP scale, developed by Bateman and Crant (1993), is comprised of 17 statements designed to elicit the respondent's views on proactive behaviour. Respondents were invited to indicate their views of each statement on a five-point scale ranging from 0 to 4 as follows: 0 (Strongly disagree), 1 (Disagree), 2 (Not sure), 3 (Agree), and 4 (Strongly agree). Likewise, the lowest score that could be obtained was 0 and the highest 68. Bateman and Crant (1993) report internal reliability with a Cronbach alpha of 0.89. By the same token, Bateman and Crant (1993) argue that the proactive scale was significantly correlated to specified criterion variables, which is indicative of criterion validity, while discriminant validity was exposed when linking PP with intelligence, neuroticism, agreeableness, openness, private self-consciousness, and locus of control.

- Part of the leadership style questionnaire developed by Avolio, Bass, and Jung (1999) was used to assess transformational leadership (TL), and it consists of 12 items (Wolins, 2012). The focus of this portion of the study will be on TL rather than transactional leadership, as Sethibe and Steyn (2016) indicate that there is no direct relationship between transactional leadership and innovation, whereas TL is positively and significantly related to innovation. Respondents were requested to indicate their views of each item on a five-point scale ranging from 0 (Not at all) to 4 (Frequently, if not always). The minimum score on the TL scale would be 0 and the maximum 48. Strydom (2013) reports a Cronbach alpha of 0.87 , whilst Sethibe and Steyn (2016) report a Cronbach alpha of 0.94 for the TL scale portion. In a study by Antonakis, Avolio, and Sivasubramanian (2003), these authors' results indicate that the questionnaire is both reliable and valid.

- The CE instrument by Strydom (2013) was chosen to quantify CE climate. The CE instrument consists of 20 items and respondents were requested to indicate their views of 
each item on a scale ranging from 1 (Strongly disagree) to 5 (Strongly agree). The minimum score on the CE instrument would be 20 and the maximum 100. A high score would indicate that respondents are of the view that there are high levels of entrepreneurial support in the organisation, while a low score would show low support for entrepreneurship (Strydom, 2013). Strydom (2013) reports an adequate reliability score (Cronbach alpha $=0.810$ ) for the total $\mathrm{CE}$ instrument. $\mathrm{CE}$ intensifies with a rise in employee engagement, organisational commitment, and job satisfaction and this is indicative of concurrent validity (Strydom, 2013). Furthermore, Strydom (2013) reports that, when the factor analysis was concluded, all items loaded as expected, with values above 0.5 , suggesting factorial validity for the CE instrument.

\subsection{Statistical Analysis}

The Statistical Package for Social Science (SPSS) was used to perform all the statistical analysis for this study. Frequencies were computed to provide biographical data on respondents.

Basic descriptive statistics were computed for the independent and dependant variables. These included means and standard deviations. Cronbach alphas were computed to confirm internal consistency (reliability) of all instruments. Hair, Black, Babin, and Anderson (2009), and Ursachi, Horodnic and Zait (2015), suggest that reliability is acceptable when the alpha is above 0.6. Therefore, all instruments with a Cronbach alpha greater than 0.6 were deemed to be internally consistent.

Correlation coefficients (for binary relationships) were also calculated between PA (as a single construct) and for innovation behaviour. Pearson correlations were used to determine the magnitude of the relationship between the variables and correlations were deemed statistically significant if at the 0.01 level. Cohen's (1988) guidelines for the social sciences to evaluate the practical significance of the alphas is as follows: $R$ above 0.5 is considered 'large', $\mathrm{R}$ above 0.3 but below 0.5 is considered 'medium', and $\mathrm{R}$ above 0.1 but below 0.3 is considered 'small'.

Regression analysis (for multiple relationships) was also calculated. This was done firstly to calculate how the different items of PA predict IWB, secondly to identify which items of PA significantly and uniquely predict IWB and, lastly, to indicate how PA and the control variables PP, CE and TL can be regressed to predict the dependent variable, IWB. The 'Enter' option in SPSS was selected for the regression analysis where all the individual PA items are regressed to predict individual innovation. In order to identify individual PA items which contribute uniquely and significantly to predicting individual innovation, 'Stepwise' regressions were performed using the 'Stepwise' option in SPSS. Finally, to assess the relative importance of PA, compared to other organisational variables, PA and the control variables PP, CE and TL were regressed to predict innovation. Once again, the 'Stepwise' procedure was followed so as to identify those variables which uniquely and significantly predict innovation.

As suggested by Pallant (2013), and Peck, Olsen and Devore (2011), the percentage variance 
in the dependent variable was calculated by multiplying the $\mathrm{R}^{2}$ value by 100 . This is also known as the coefficient of determination.

\section{Results}

\subsection{Biographical Data}

Complete data was available for 3180 employees from 53 organisations. There composition is described below.

Gender: The respondents in this study were categorised into two gender groups. The 2016 Quarterly Labour Force Survey indicates that the gender demographic across South Africa as a whole is almost equally distributed (Statistics South Africa, 2016), and this is closely aligned to the gender sample in this study. A total of 1771 (55.7\%) respondents recorded their gender as male, and $1372(43.1 \%)$ recorded their gender as female, whilst the missing data amounted to $37(1.2 \%)$.

Race: The respondents in this study were categorised into four race groups, and this data is aligned to the Quarterly Labour Force Survey in the sense that, in the larger South African context, Black people make up the largest workforce group, followed by White people, Coloured people, and Asian people in descending order (Statistics South Africa, 2016). A total of $263(8.3 \%)$ respondents in this study marked Asian people, 1830 (57.5\%) Black people, $263(8.3 \%)$ Coloured people, and 787 (24.7\%) White people, while the missing data is $37(1.2 \%)$.

Age: The 2016 Quarterly Labour Force Survey indicates that the age of the South African workforce ranges from 15 to 64 years (Statistics South Africa, 2016), and this is closely aligned to the respondents in this study whose ages range from 20 to 72 years, with a mean of 37.81 and a standard deviation of 9.10 .

Educational qualifications: A total of 934 (29.4\%) respondents hold a bachelor's degree or higher, $1274(40.1 \%)$ possess a diploma, $789(24.8 \%)$ have matric, and $143(4.5 \%)$ have less than 12 years of schooling, while the missing data is $40(1.3 \%)$.

Management and tenure: Those in management positions totalled 1156 (36.4\%) and those in non-management positions represented 1983 (62.4\%), while the missing data was 40 $(1.3 \%)$. As far as tenure at their present company is concerned, this varied between one month and 42 years, with a mean of 8.49 and a standard deviation of 7.45.

Economic sectors: The companies in this study were categorised into three sectors already alluded to. A total of $1981(62.3 \%)$ respondents fall within the private sector, $480(15.1 \%)$ are parastatal, and 719 (22.6\%) are government departments, for example, the Department of Trade and Industry, the Department of Tourism, and so on.

From the above, it is clear that the respondents represent a broad cross-section of the South African working population.

\subsection{Descriptive Data}




\section{Macrothink}

International Journal of Human Resource Studies

ISSN 2162-3058

2020, Vol. 10, No. 2

Table 1 presents the means and standard deviations of all constructs included in this study, as well as for the individual PA items. Cronbach alphas for the instruments are also presented in the last column.

Table 1. Descriptive data $(\mathrm{N}=3$ 180)

\begin{tabular}{|c|c|c|c|c|}
\hline $\begin{array}{l}\text { PA items } \\
\text { / Scale }\end{array}$ & Item content & Mean & Std. Dev. & $\alpha$ \\
\hline $\mathrm{PA}_{1}$ & $\begin{array}{l}\text { The PA system at my organisation is the primary } \\
\text { mechanism used to assess the performance of the } \\
\text { employees. }\end{array}$ & 3.586 & 1.296 & $\mathrm{~N} / \mathrm{A}$ \\
\hline $\mathrm{PA}_{2}$ & $\begin{array}{l}\text { I received formal training on the PA system used } \\
\text { by my organisation and understand the system } \\
\text { fully. }\end{array}$ & 3.193 & 1.449 & N/A \\
\hline $\mathrm{PA}_{3}$ & $\begin{array}{l}\text { The consequences and rewards allocated are } \\
\text { reflective of the individuals' scores or rating on } \\
\text { the PA system. }\end{array}$ & 3.210 & 1.357 & N/A \\
\hline $\mathrm{PA}_{4}$ & $\begin{array}{l}\text { All the performance targets set and recorded on } \\
\text { the PA system add significant value to the success } \\
\text { of the business. }\end{array}$ & 3.373 & 1.302 & N/A \\
\hline $\mathrm{PA}_{5}$ & $\begin{array}{l}\text { Only elements relevant to the success in my job } \\
\text { are assessed and all elements relevant to success } \\
\text { in my job are included in the performance } \\
\text { standard. }\end{array}$ & 3.275 & 1.260 & N/A \\
\hline $\mathrm{PA}_{6}$ & $\begin{array}{l}\text { My manager consistently gives me higher or } \\
\text { lower marks than what a fair rater would do. }\end{array}$ & 3.352 & 1.330 & N/A \\
\hline $\mathrm{PA}_{7}$ & $\begin{array}{l}\text { When my performance stays consistent, but } \\
\text { factors beyond my control cause a decline in my } \\
\text { outputs, my PA remains consistent. }\end{array}$ & 2.979 & 1.291 & N/A \\
\hline $\mathrm{PA}_{8}$ & $\begin{array}{l}\text { The PA system is not biased and differentiates } \\
\text { between the more effective and less effective } \\
\text { performers. }\end{array}$ & 3.055 & 1.321 & N/A \\
\hline $\mathrm{PA}_{9}$ & $\begin{array}{l}\text { The PA system in my organisation is easy to } \\
\text { administer, from the perspective of both the }\end{array}$ & 3.101 & 1.341 & N/A \\
\hline
\end{tabular}




\begin{tabular}{|c|c|c|c|c|}
\hline $\begin{array}{l}\text { PA items } \\
\text { / Scale }\end{array}$ & Item content & Mean & Std. Dev. & $\alpha$ \\
\hline & manager and the subordinate. & & & \\
\hline $\mathrm{PA}_{10}$ & $\begin{array}{l}\text { The PA system is accepted and supported by all } \\
\text { parties in my organisation. }\end{array}$ & 3.055 & 1.328 & N/A \\
\hline $\mathrm{PA}_{11}$ & $\begin{array}{l}\text { The decisions that are made on the grounds of the } \\
\text { PAs are relevant, sound and do not often lead to } \\
\text { labour disputes. }\end{array}$ & 3.114 & 1.288 & N/A \\
\hline $\mathrm{PA}_{12}$ & $\begin{array}{l}\text { The PA system is well aligned with the business } \\
\text { strategy. }\end{array}$ & 3.325 & 1.291 & N/A \\
\hline $\mathrm{PA}_{13}$ & $\begin{array}{l}\text { Managers negotiate each of their team member's } \\
\text { specific, measurable and stretching performance } \\
\text { targets. }\end{array}$ & 3.247 & 1.302 & N/A \\
\hline $\mathrm{PA}_{14}$ & $\begin{array}{l}\text { Managers regularly review both unit and } \\
\text { individual performance with those concerned and } \\
\text { take appropriate action to ensure that targets are } \\
\text { reached or exceeded. }\end{array}$ & 3.181 & 1.320 & N/A \\
\hline $\mathrm{PA}_{15}$ & $\begin{array}{l}\text { The effectiveness of the performance } \\
\text { management system is formally evaluated at least } \\
\text { once a year and appropriate improvements are } \\
\text { made for the next cycle. }\end{array}$ & 3.229 & 1.327 & N/A \\
\hline $\mathrm{PA}_{16}$ & $\begin{array}{l}\text { My input is taken into consideration for the } \\
\text { improvements of the PA system for the next cycle. }\end{array}$ & 2.946 & 1.352 & N/A \\
\hline $\mathrm{PA}_{17}$ & $\begin{array}{l}\text { Continuous assessment of my performance is } \\
\text { being done regularly and recorded. }\end{array}$ & 3.306 & 1.282 & N/A \\
\hline $\mathrm{PA}_{18}$ & $\begin{array}{l}\text { Formal feedback on my final PAs feedback is } \\
\text { given by my manager. }\end{array}$ & 3.607 & 1.326 & N/A \\
\hline PA & Performance Appraisal & 58.133 & 16.072 & 0.930 \\
\hline IWB & Innovative Work Behaviour & 52.988 & 13.173 & 0.893 \\
\hline
\end{tabular}




\begin{tabular}{|l|l|l|l|l|}
\hline $\begin{array}{l}\text { PA items } \\
\text { / Scale }\end{array}$ & Item content & Mean & Std. Dev. & $\boldsymbol{\alpha}$ \\
\hline PP & Proactive Personality & 53.792 & 8.971 & 0.843 \\
\hline CE & Corporate Entrepreneurship & 65.743 & 9.321 & 0.762 \\
\hline TL & Transformational Leadership & 2.516 & 0.972 & 0.946 \\
\hline
\end{tabular}

As reflected in Table 1, the individual PA item scores varied, with PA16 showing the lowest mean $($ mean=2.946; standard deviation=1.352) and PA18 showing the highest (mean=3.607; standard deviation=1.326).

\subsection{Reliability}

As can be seen from Table 1, PA registers a high internal consistency (Cronbach alpha=0.930). Reliability was also calculated for the IWB questionnaire (0.893), the 17-item PP scale (0.843), the 20-item CE instrument (0.762) and lastly for the 12-item TL scale (0.946). All five scales have a Cronbach alpha above 0.6, which means that the reliability of all scales is acceptable.

\subsection{Correlation and Regression Analysis}

Table 2 presents the results pertaining to the relationship between PA and innovation.

Table 2. Total sample correlative and regression analysis $(\mathrm{N}=3$ 180)

\begin{tabular}{|c|c|c|c|c|}
\hline Column 1 & Column 2 & Column 3 & Column 4 & Column 5 \\
\hline $\begin{array}{l}\text { Measure } \\
\text { of } \\
\text { innovation }\end{array}$ & $\begin{array}{l}\text { PA and } \\
\text { innovation }\end{array}$ & $\begin{array}{l}\text { All items of } \\
\text { PA and } \\
\text { innovation }\end{array}$ & $\begin{array}{l}\text { All items of PA and } \\
\text { innovation (optimal } \\
\text { model) }\end{array}$ & $\begin{array}{l}\text { PA and innovation } \\
\text { with other control } \\
\text { variables }\end{array}$ \\
\hline IWB & $\begin{array}{l}\mathrm{R}=0.239 \\
p<0.01\end{array}$ & $\begin{array}{l}\mathrm{R}_{\text {adjusted }}^{2}=0.106 \\
p<0.01\end{array}$ & $\begin{array}{l}\mathrm{R}_{\text {adjusted }}^{2}=0.105 ; \\
p<0.01 ; \\
\text { Items } 13,17,4,16,2 \text {, } \\
15,1 \text { and } 5\end{array}$ & $\begin{array}{l}\mathrm{R}_{\text {adjusted }}^{2}=0.266 ; \\
p<0.01 \text {; Scales: PP, } \\
\text { PA, CE, TL }\end{array}$ \\
\hline
\end{tabular}

In column 2, depicting the relationship between PA (as a composite score) and individual innovation, it can be reported that $\mathrm{R}=0.239$ for IWB. The correlation coefficient was statistically significant. When considering the practical significance, R for IWB is 'small'. Considering the coefficient of determination, $5.7 \%$ of the variance in IWB could be declared by PA. It is, therefore, practically insignificant.

The results of the regression are presented in column 3 where all the individual PA items of 
the PA instrument are regressed to predict individual innovation. The 'Enter' option in SPSS was selected for this analysis. It can be reported that $\mathrm{R}_{\text {adjusted }}^{2}=0.106$ for IWB, depicting the relationship between all items of PA and innovation. The correlation coefficient was statistically significant. When considering the practical significance, $\mathrm{R}^{2}$ adjusted for IWB is 'small'. Using all the items of the PA questionnaire allowed for $10.6 \%$ of the variance in IWB to be declared. Though this is still practically insignificant, it seems that the items are a better predictor of innovation than are the aggregate scores.

In order to identify those individual PA items which contribute uniquely and significantly to predicting individual innovation, 'Stepwise' regressions were performed using the 'Stepwise' option in SPSS. From column 4, it can be read that items 13, 17, 4, 16, 2, 15, 1 and 5 (listed in descending order of influence on innovation) of the PA questionnaire are the elements of PA which influence IWB uniquely and significantly.

Items predicting IWB read as follows:

- Item 1: The PA system at my organisation is the primary mechanism used to assess the performance of the employees.

- Item 2: I received formal training on the PA system used by my organisation and understand the system fully.

- Item 4: All the performance targets set and recorded on the PA system add significant value to the success of the business.

- Item 5: Only elements relevant to the success in my job are assessed and all elements relevant to success in my job are included in the performance standard.

- Item 13: Managers negotiate each of their team member's specific, measurable and stretching performance targets.

- Item 15: The effectiveness of the performance management system is formally evaluated at least once a year and appropriate improvements are made for the next cycle.

- Item 16: My input is taken into consideration for the improvements of the PA system for the next cycle.

- Item 17: Continuous assessment of my performance is being done regularly and recorded.

From the above, it is clear that eight out of the 18 items are predictors of innovation. Central to IWB seems to be managers who negotiate specific, measurable and stretching performance targets with each of their team members.

To assess the relative importance of PA, compared to other organisational variables, PA and the control variables PP, CE and TL were regressed to predict innovation. Once again, the 'Stepwise' procedure was followed so as to identify those variables which uniquely and significantly predict innovation. In the comprehensive model, where the different antecedents were included, $26.6 \%$ of the variance in IWB was explained (column 5). This is compared to 
the $10.6 \%$ variance explained to PA as an individual predictor (column 3). It can also be reported from column 5 that the variables, PP, PA, CE, and TL (listed in descending order of influence on innovation) have a substantial influence on IWB. In the case of IWB, PA was the second most important predictor. Importantly to note was that all the independent variables were included in the model presented, suggesting that they are all antecedents to innovation.

\section{Discussion}

Following from the literature review, it is clear that the PA-innovation link focuses mostly on Western samples. The sample presented in this study addresses this concern and the research investigate the phenomena within the South African context. Furthermore, the respondents represented the South African workforce well, in as far as gender, race, and age were concerned. In addition, the biographical data was closely aligned with information presented in the Quarterly Labour Force Survey publication (Statistics South Africa, 2016).

Previous studies on the link between PA and innovation have been criticised for focusing only on a single-company or on a single-industry with relatively small samples. This research makes use of a large sample, across multiple organisations in different sectors. The study involved 3180 employees from 53 companies, thus addressing the mentioned concern.

Previous research on the PA-innovation link has also been criticised for focusing only on PA as a free-standing construct, and not integrating it with other possible antecedents. This study addresses this issue by also including several other measures, namely TL, PP, and CE in the model.

The results showed that the relationship between PA (as a total score) and individual innovation, although statistically significant, was practically insignificant $(5.7 \%$ of the variance declared). The relationship between all items of PA and innovation was also statistically significant and practically insignificant (10.6\% of the variance declared). The relationship when using all items, however, was larger than when using the total score. This may suggest that the certain individual items are better predictors of innovation.

Focusing on the individual PA items, the results showed that some were more effective in predicting innovation than others. For these items, it may be deduced that these elements of PA are the primary drivers of innovation. These can collectively be described as a PA system depicted by negotiated, specific, measurable and stretching performance targets.

It is clear from the findings that considering PA as an 'independent' predictor of innovation across organisations does not lend support for PA as one of the antecedents to innovation. This is inconsistent with the research conducted by Aktharsha and Sengottuvel (2016), Choi et al. (2013), Dalota and Perju (2010) and Runfeng (2011). Practically significant PA-innovation relationships were not found here, but may be found in individual organisations, rather than across organisations as it was tested in this research.

The variables, PP, PA, CE, and TL (listed in descending order of influence on innovation) influence IWB. In the case of IWB, PA was the second most important predictor. It can be seen that PA, among other variables, is responsible for innovation. This conclusion is aligned 
with the findings of Bal et al. (2014), Jimenez-Jimenez and Sanz-Valle (2005), Mark and Akhtar (2003) and Shipton et al. (2006). The results also demonstrate that PA is a far more important driver of innovation than, for example, TL. PP has the most significant influence on IWB compared to the other variables. This places PA as an antecedent to innovation within the context of other variables.

\section{Theoretical Implications}

The research contributes to academic literature and theory on PA and innovation within the South African context, where no previous study of this nature has been conducted. The research specified the importance of PA in general, as well as the relative importance of PA as an antecedent to innovation in the workplace. Specifically, the research demonstrates that PA is a significant but small driver of innovation, which accounts for about $10 \%$ of the variance in innovation. It has also been established that there are other variables that have a far more significant influence on innovation than PA, specifically PP. This research has thus led to an increase in knowledge and new discoveries on the PA-innovation link.

\section{Practical Implications}

The outcomes or results of the study have the potential to benefit all business stakeholders and may also assist managers and human resource practitioners to identify which PA practices enhance innovation. Moreover, the identified practices will allow human resource practitioners and managers to enrich their current PA processes in an effort to enhance innovation. In addition, the magnitude of the relationship has been quantified and human resource practitioners are alerted to the relative role of PA as a predictor of innovation. Although the study has provided evidence that PA has a role to play in influencing innovation within an organisation, it is clear that PP is central to innovation, and that TL has a less significant role to play. Focusing on the recruitment of proactive employees, rather than on managing them with TL practices, may be at the root of innovation in organisations. This knowledge would help managers improve innovation behaviour and thereby increase competitive advantage.

\section{Limitations of the Study}

The present study was subject to a few limitations that are worth mentioning. The first limitation is that the study design is cross-sectional in nature. Cross-sectional studies are conducted at a specific point in time and provide no indication of the sequence of events, thus making it impossible to infer causality from the study (Levin, 2006). Therefore, longitudinal or experimental studies are suggested to overcome the limitations of a cross-sectional study. The second limitation was the exclusive use of respondents' perceptions in this study. The results may have been more explanatory had managers been included in the reporting or had organisational statistics, such as registered patents, been used. Multi-source and multi-method research is suggested. A third limitation was that the respondents represented the South African workforce as a single unit. It can be expected that there may be differences per organisation and also sector-wide, and research in this regard is therefore recommended. 


\section{Acknowledgements}

Competing interests

The authors declare that they have no financial or personal relationships that may have inappropriately influenced them in writing this article.

\section{Author contributions}

N.G.M. was the main author of the article. R.S. was the supervisor of N.G.M and the co-author of the article.

\section{References}

Abbaspour, P. (2015). Effect of strategic orientation and HRM strategies on organisational strategic performance: Examining mediating role of strategic learning and innovation. An International Peer-reviewed Journal (Trends in Life Sciences), 4(4), 125-132.

Ahmed, I., Mohammad, S. K., \& Islam, T. (2013). The relationship between perceived fairness in performance appraisal and organisational citizenship behaviour in the banking sector of Pakistan: The mediating role of organisational commitment. International Journal of Management and Innovation, 5(2), 75-88.

Akman, G., \& Yilmaz, C. (2008). Innovative capability, innovation strategy and market orientation: An empirical analysis in Turkish software industry. International Journal of Innovation Management, 12(1), 69-111. https://doi.org/10.1142/S1363919608001923

Aktharsha, U. S., \& Sengottuvel, A. (2016). Knowledge sharing behaviour and innovation capability: HRM practices in hospitals. SCMS Journal of Indian Management, 13(1), 118-130.

Antonakis, J., Avolio, B. J., \& Sivasubramanian, N. (2003). Context and leadership: An examination of the nine-factor full-range leadership theory using the Multifactor Leadership Questionnaire. The Leadership Quarterly, 14(2003), 261-295. https://doi.org/10.1016/S1048-9843(03)00030-4

Avolio, B. J., Bass, B. M., \& Jung, D. I. (1999). Re-examining the components of transformational and transactional leadership using the Multifactor Leadership Questionnaire. Journal of Occupational and Organisational Psychology, 72(4), 441-462. https://doi.org/10.1348/096317999166789

Bal, Y., Bozkurt, S., \& Ertemsir, E. (2014). A study on determining the relationship between strategic HRM practices and creating innovation in organisations. The International Journal of Contemporary Management, 13(2), 23-36.

Bateman, T. S., \& Crant, J. M. (1993). The proactive component of organisational behaviour: A measure that correlates. Journal of Organisational Behaviour, 14(2), 103-118. https://doi.org/10.1002/job.4030140202 
Boswell, W. R., \& Boudreau, J. W. (2000). Employee satisfaction with performance appraisals and appraisers: The role of perceived appraisal use. Human Resource Development Quarterly, $11(3)$ 283-299. https://doi.org/10.1002/1532-1096(200023)11:3\%3C283::AID-HRDQ6\%3E3.0.CO;2-3

Bryman, A. D. (2012). Social research methods. (4 ${ }^{\text {th }}$ ed.). New York: Oxford University Press.

Cascio, W. F. (2010). Managing human resources: Productivity, quality of work life, profits. ( $8^{\text {th }}$ ed.). New York: McGraw-Hill Irwin.

Ceylan, C. (2013). Commitment-based HR practices, different types of innovation activities and firm innovation performance. International Journal of Human Resource Management, 24(1), 208-226. https://doi.org/10.1080/09585192.2012.680601

Chen, C., \& Huang, J. (2009). Strategic human resource practices and innovation performance: The mediating role of knowledge management capacity. Journal of Business Research, 62(1), 104-114. https://doi.org/10.1016/j.jbusres.2007.11.016

Choi, B. K., Moon, H. K., \& Ko, W. (2013). An organisation's ethical climate, innovation, and performance: Effects of support for innovation and performance evaluation. Management Decision, 51(6), 1250-1275. https://doi.org/10.1108/MD-Sep-2011-0334

Cohen, J. (1988). Statistical power analysis for the behavioral sciences. ( $2^{\text {nd }}$ ed.). New Jersey: Lawrence Erlbaum Associates.

Dalota, M., \& Perju, A. (2010). Human resource management and the company's innovation. Romanian Economic and Business Review, 5(4), 122-131.

De Jong, J., \& Den Hartog, D. (2010). Measuring innovative work behaviour. Creativity and Innovation Management, 19(1), 23-36. https://doi.org/10.1111/j.1467-8691.2010.00547.x

DeNisi, A. S., \& Pritchard, R. D. (2006). Performance appraisal, performance management and improving individual performance: A motivational framework. Management and Organisation Review, 2(2), 253-277. https://doi.org/10.1111/j.1740-8784.2006.00042.x

Esu, B. B., \& Inyang, B. J. (2009). A case for performance management in the public sector in Nigeria. International Journal of Business and Management, 4(4), 98-105. https://doi.org/10.5539/ijbm.v4n4p98

Grobler, P. A., Wärnich, S., Carrell, M. R., Elbert, N. F., \& Hatfield, R. D. (2006). Human resource management in South Africa. ( ${ }^{\text {rd }}$ ed.). London: Thompson Learning.

Grobler, P. A., Wärnich, S., Carrell, M. R., Elbert, N. F., \& Hatfield, R. D. (2011). Human resource management in South Africa. ( $4^{\text {th }}$ ed.). Hampshire: Cengage Learning.

Grote, R. C. (1996). The complete guide to performance appraisal. (1 ${ }^{\text {st }}$ ed.). New York: AMACOM. 
Hair, J. F., Black, W. C., Babin, B. J., \& Anderson, R. E. (2009). Multivariate data analysis. ( $7^{\text {th }}$ ed.). Upper Saddle River, NJ: Pearson Education International.

Hurley, R. F., \& Hult, G. T. M. (1998). Innovation, market orientation, and organisational learning: An integration and empirical examination. The Journal of Marketing, 62(1), 42-54. https://doi.org/10.1177/002224299806200303

Jimenez-Jimenez, D., \& Sanz-Valle, R. (2005). Innovation and human resource management fit: An empirical study. International Journal of Manpower, 26(4), 364-381. https://doi.org/10.1108/01437720510609555

Judge, T. A., \& Ferris, G. R. (1993). Social context of performance evaluation decisions. Academy of Management Journal, 36(1), 80-105. https://doi.org/10.2307/256513

Khan, M. F. U. (2013). Role of performance appraisal system on employee motivation. Journal of Business and Management, 8(4), 66-83. https://doi.org/10.9790/487X-0846683

Khoury, G. C., \& Analoui, F. (2004). Innovative management model for performance appraisal: The case of the Palestinian public universities. Management Research News, 27(1), 56-73. https://doi.org/10.1108/01409170410784356

Levin, K. A. (2006). Study design III: Cross-sectional studies. Evidence-Based Dentistry, 7(1), 24-25. https://doi.org/10.1038/sj.ebd.6400375

Ling, T. C., \& Nasurdin, A. M. (2011). Human resource management practices and organisational innovation: Assessing the mediating role of knowledge management effectiveness. Electronic Journal of Knowledge Management, 9(2), 155-167.

Mark, S. K. M., \& Akhtar, S. (2003). Human resource management practices, strategic orientations, and company performance: A correlation study of publicly listed companies. Journal of American Academy of Business, 2(2), 510-515.

Matthew, A. (2014). Human resource management: The enabler of innovation in organisations. BVIMR Management Edge, 7(1), 53-59.

Michaelis, B., Stegmaier, R., \& Sonntag, K. (2010). Shedding light on followers' innovation implementation behaviour: The role of transformational leadership, commitment to change, and climate for initiative. Journal of Managerial Psychology, 25(4), 408-429. https://doi.org/10.1108/02683941011035304

Muller, A., Valikangas, L., \& Merlyn, P. (2005). Metrics for innovation: Guidelines for developing a customised suite of innovation metrics. Strategy and Leadership, 33(1), 37-45. https://doi.org/10.1108/10878570510572590

Nankervis, A. R., \& Compton, R. L (2006). Performance management: Theory in practice? Asia Pacific Journal of Human Resources, 44(1), 83-101. https://doi.org/10.1177/1038411106061509

Pallant, J. (2013). SPSS survival manual: A step by step guide to data analysis using IBM SPSS. (5 ${ }^{\text {th }}$ ed.). New York: McGraw-Hill. 
Panuwatwanich, K., Stewart, R. A., \& Mohamed, S. (2008). Enhancing innovation and firm performance: The role of climate for innovation in design firms. Proceedings of the $5^{\text {th }}$ International Conference on Innovation in Architecture, Engineering and Construction, (pp.23-25). Antalya, Turkey. https://doi.org/10.1108/09699980810902712

Parker, S. K., Williams, H. M., \& Turner, N. (2006). Modeling the antecedents of proactive behaviour at work. Journal of Applied Psychology, 91(3), 636-652. https://doi.org/10.1037/0021-9010.91.3.636

Paulsen, N., Callan, V. J., Ayoko, O., \& Saunders, D. (2013). Transformational leadership and innovation in an R\&D organisation experiencing major change. Journal of Organisational Change Management, 26(3), 595-610. https://doi.org/10.1108/09534811311328597

Peck, R., Olsen, C., \& Devore, J. L. (2011). Introduction to statistics and data analysis. (4 ${ }^{\text {th }}$ ed.). Boston, MA: Brooks/Cole.

Punch, K. F. (1998). Introduction to social research: Quantitative and qualitative approaches. ( $1^{\text {st }}$ ed.). London: SAGE Publications, Inc.

Runfeng, Y. (2011). Influence of goal orientation in performance appraisal on staff innovative behaviour: mediating effect of innovative climate. Proceedings of the $8^{\text {th }}$ International Conference on Innovation and Management, (pp.445-451). Kitakyushu, Japan.

Ryakhovskaya, A. N., Gruzina, Y. M., Arsenova, E. V., Linder, N. V., \& Pukhova, M. M. (2015). Development of methodology for performance assessment and the effectiveness of innovation activity. Mediterranean Journal of Social Sciences, 6(5 S4), 189-196. https://doi.org/10.5901/mjss.2015.v6n5s4p189

Seibert, S. E., Kraimer, M. L., \& Crant, J. M. (2001). What do proactive people do? A longitudinal model linking proactive personality and career success. Personnel Psychology, 54(4), 845-874. https://doi.org/10.1111/j.1744-6570.2001.tb00234.x

Sethibe, T., \& Steyn, R. (2015). The relationship between leadership styles, innovation and organisational performance: A systematic review. South African Journal of Economic and Management Sciences, 18(3), 325-337. https://doi.org/10.17159/2222-3436/2015/v18n3a3

Sethibe, T., \& Steyn, R. (2016). Towards a comprehensive model on the relationship between leadership styles, organisational climate, innovation and organisational performance. Midrand: University of South Africa.

Shanker, R., Bhanugopan, R., \& Fish, A. (2012). Changing organisational climate for innovation through leadership: An exploratory review and research agenda. Review of Management Innovation \& Creativity, 5(14), 105-118.

Shipton, H., West, M. A., Dawson, J., Birdi, K., \& Patterson, M. (2006). HRM as a predictor of innovation. Human Resource Management Journal, 16(1), 3-27. https://doi.org/10.1111/j.1748-8583.2006.00002.x 
Siaguru, F. (2011). Performance appraisal systems: Procedural and implementation issues in Papua New Guinea. Journal of Management Policy and Practice, 12(5), 116-127.

Statistics South Africa. (2016). Quarterly labour force survey - Quarter 4: 2016 (Statistical release P0211). Retrieved 5 March 2017, from Statistics South Africa website: http://www.statssa.gov.za/publications/P0211/P02114thQuarter2016.pdf

Steyn, R. (2010). The development and validation of the quality of performance appraisal systems questionnaire. Paper presented at the $27^{\text {th }}$ International Congress of Applied Psychology, (pp.947). Melbourne, Australia.

Strydom, A. S. (2013). The influence of organisational behaviour variables on corporate entrepreneurship. Midrand: University of South Africa.

Swanepoel, B. J., Erasmus, B. J., \& Schenk, H. W. (2008). South African human resource management: Theory \& practice. ( $4^{\text {th }}$ ed.). Cape Town: Juta \& Co Ltd.

Tai, H. T., \& Mai, N. Q. (2016). Proactive personality, organisational context, employee creativity and innovative capability: Evidence from MNCs and domestic corporations. International Journal of Organisational Analysis, 24(3), 370-389. https://doi.org/10.1108/IJOA-04-2015-0857

Thomas, J. P., Whitman, D. S., \& Viswesvaran, C. (2010). Employee proactivity in organisations: A comparative meta-analysis of emergent proactive constructs. Journal of $\begin{array}{llll}\text { Occupational \& Organisational Psychology, } & 83(1), \quad 275-300 .\end{array}$ https://doi.org/10.1348/096317910X502359

Tipu, S., Ryan, J., \& Fantazy, K. (2012). Transformational leadership in Pakistan: An examination of the relationship of transformational leadership to organisational culture and innovation propensity. Journal of Management \& Organisation, 18(4), 461-480. https://doi.org/10.5172/jmo.2012.997

Ursachi, G., Horodnic, I. A., \& Zait, A. (2015). How reliable are measurement scales? External factors with indirect influence on reliability estimators. Procedia Economics and Finance, 20(1), 679-686. https://doi.org/10.1016/S2212-5671(15)00123-9

Wolins, R. G. (2012). Everyday optimum leadership: Practicing servant leadership - other centred focused. ( $1^{\text {st }}$ ed.). Bloomington: West Bow Press.

Wu, H., Sears, L. E., Coberley, C. R., \& Pope, J. E. (2016). Overall well-being and supervisor ratings of employee performance, accountability, customer service, innovation, presocial behaviour, and self-development. Journal of Occupational and Environmental Medicine, 58(1), 35-40. https://doi.org/10.1097/JOM.0000000000000612

Zhang, Y., \& Begley, T. M. (2011). Perceived organisational climate, knowledge transfer and innovation in China-based research and development companies. The International Journal of Human Resource Management, $\quad 22(1), \quad 34-56$. https://doi.org/10.1080/09585192.2011.538967 


\section{Copyright Disclaimer}

Copyright for this article is retained by the author(s), with first publication rights granted to the journal.

This is an open-access article distributed under the terms and conditions of the Creative Commons Attribution license (http://creativecommons.org/licenses/by/4.0/). 